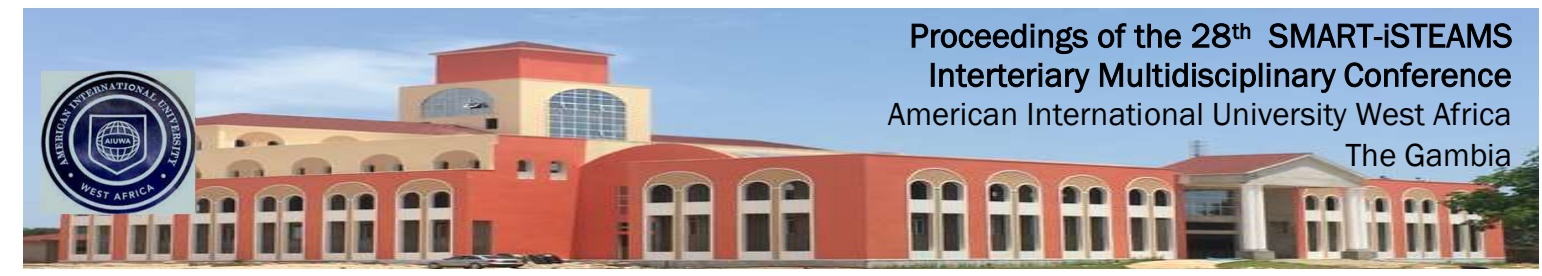

\title{
Full Position Paper
}

\section{Law, Politics and Leadership in Contemporary Africa - An Examination of Facts}

\section{Nwele, J. Obasi, PhD}

Office of the Vice Chancellor Head of Quality Assurance \& Legal Unit, American International University, West Africa, The Gambia

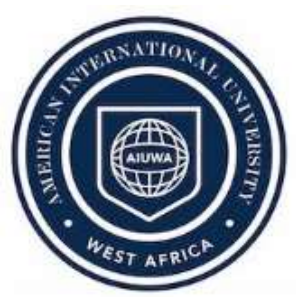

E-mail nwele.obasi@aiu.edu.gm obasijen@yahoo.com

Phones

$+2203612785$

$+2207026523$

\begin{abstract}
Every society need to deal with legal matters, solve political and leadership problems, and, because of the nature of legal, political and leadership tasks as daunting issue, a scholarly solicitor and/or advocacy approach may be very necessary to prevent disputes and prosecution problems of leadership issue in Africa. Corruption and Fraud has been an endemic issue in the global political affairs for ages, and recently cybercrime has joined the litany of the cankerworm that impede success of democracy and development and social tranquility of nations, especially arising from electoral issue fraud. To control and manage human resource capital, in relation to stock of or supply of mineral resources, material and financial, money, and other assets that can be drawn on by a person, organization or state, to establish an effective and viable economy, individuals, organizations and governments need to maintain a truly leadership principles and political order that follow rules of law. It is a fact that Africa as a part of the world, especially in the new global politics tries to align to the protection of its environment against corruption and fraud. This study examines the level, and the indices of corruption and fraud in relation to true leadership principles and political order that follow rules of law in Africa. Primary and secondary data were used in this research, which aims at discovering appropriate measures to squarely or effectively address crimes related to misuse of political and leadership powers and corruption, economic fraud and cybercrime in Africa. Binary logistic regression and chi-square were applied. The findings reveal that economic development, politics, democracy and rule of law has a nexus to addressing the complex nature of entrenching true democracy; fighting corruption, fraud, and cybercrime in individual, organization, and government. The findings further indicate that coordinated and coherent academic/intellectual crossroad crusade is what is needed/required to restore Africa to glory land.
\end{abstract}

Keywords: Law, Politics, Leadership, Contemporary Africa, Corruption, Fraud, Cybercrime, Economic Development

Proceedings Reference Format

Nwele, J. Obasi (2021): Law, Politics and Leadership in Contemporary Africa - An Examination of Facts Proceedings of the 28th iSTEAMS Intertertiary Multidisciplinary Conference. American International University West Africa, The Gambia. Series 28, Vol 3 October, 2021. Pp 55-66 www.isteams.net/gambia2021.

DOI - https://doi.org/ 10.22624/AIMS/iSTEAMS-2021/V28N3P6 


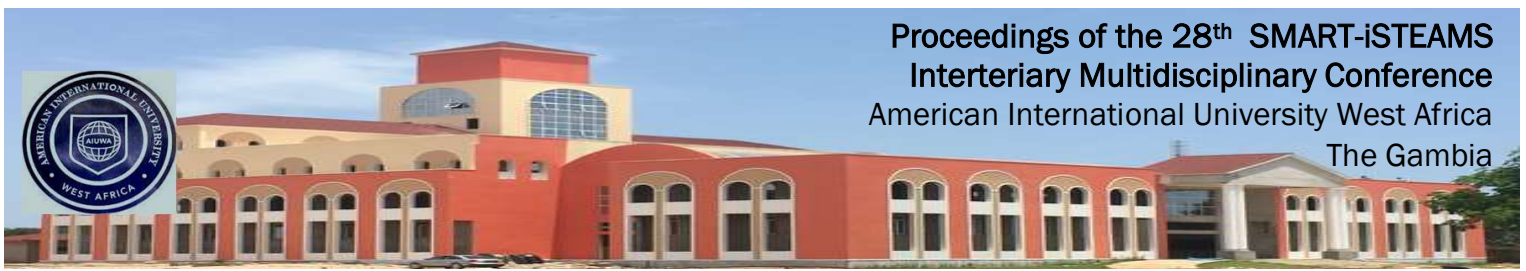

\section{INTRODUCTION}

\subsection{Leadership and Leadership Economics}

Leadership is about setting direction, building an inspiring vision, and creating new goals that are dynamic, exciting, and inspiring, especially creating a desirable work culture that attracts and retains high-performing talent, empowers employees, and values entrepreneurship. With major changes and new emphases appearing on the development scene of a new world where technologies are becoming widely available and management of government services gradually being relocated closer to the users, there are the lessons of economics - economics of law, political economics, economics of leadership. This study deals with the economics of diagnosing capacity and competence in relation to leadership that makes and implements the rules of law, and, political order that curbs corruption and fraud in a society, for the real economics and economic development of nations in Africa.

Economics is a branch of business studies that deals with all the aspects of a country's economy, such as how a country uses its resources, the outcome of investing in industries and/or financial products, including how much time labourers spend or devote to work and leisure, the effect of taxation on a population and business organisations, why businesses succeed or fail. Like in business and marketing, economics is concerned with the realities of life under three concepts: What to produce, and in what quantity; How to produce it; and, for whom? Business, Economics and Marketing, are all about critical analysis of costs and the benefits accruing to the cost. While financial economics as a branch of economics analyses the use of and distribution of resources in individuality, markets, organization or state, in which decisions are made under certainty and uncertainty(s).

On the other hand, the decisions to be made often considers want satisfying index of stocks, portfolios or the market. The economic theory in use in financial economics evaluates how time and risk with opportunity costs, including relative information can create incentives or otherwise for a particular decision. Rational and irrational behaviors of marketers are part of what financial economics take into account to decision table.

In the words of Whitney Sherry, "Economics is the study of the production and consumption of goods and the transfer of wealth to produce and obtain those goods." Economics explains how people interact within markets to get what they want or accomplish certain goals. Then comes, the micro and macro concept: the individual and industries and then the entire country or international marketplace. According to the Quality Assurance Agency for Higher Education, Economics is the 'study of the factors that influence income, wealth and well-being.' It is a Social Science which incorporates mathematics and statistics as well as having connections with the physical sciences (biology, medicine and Physics) and many other disciplines (politics, law, geography, psychology, etc).

\footnotetext{
${ }^{1}$ Nwele Obasi Law and practice of management in a contemporary society seminar in management class project report Renaissance University Enugu state (2014)
} 


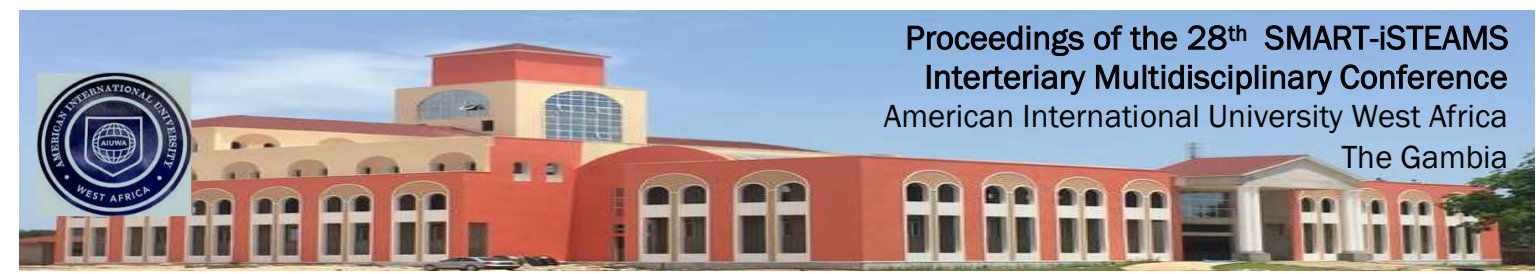

\section{Economic Development}

Refers to the sustained, concerted actions of communities and policy makers that improve the standard of living and economic health of a specific locality or society.

Like in business and marketing, economics is concerned with the realities of life under three concepts: What to produce, and in what quantity; How to produce it; and, for whom? Economics is a social science that study human behavior between ends and scarce means which have alternative uses. How to produce it.

\section{What is it that defines Leadership?}

Leadership is the process of social influence based on ability of individual or group of individuals which guides followers or other member of an entity.

\section{i). Vision, \& Mission \\ ii). Communication \\ iii). Empathy \\ iv) Motivational Spirit \\ iv). Accountability, and \\ v). Gratitude}

Essential Qualities of a Good Leader:

Charismatic leaders are transformative, and team-oriented, they develop a vision and inspire others to follow them towards it. They communicate well to other group leaders and to all stakeholders to get everyone on board with their vision. They deal with challenging situations because they can see the ball trend. The stakeholders are more likely to feel a corporate fit and stay with them, to bring increased effectiveness to corporate existence. Democracy is meant to guarantee personal freedom among the people of a democratic society but does that happen in Africa? We cannot fight poverty by giving hand-out, we can only fight poverty by helping the poor with what they need (the tools) to fight poverty. ${ }^{2}$

\section{Law}

Law on its own is a body of official rules and regulations, generally found in constitutions, legislations, judicial opinion, and similar provisions that is used to govern a society and to control the behaviour of its members. The Nature and functions of law have varied throughout history. In modern societies, some authorized body such as a legislature or a court makes law. This law is backed by the coercive power of the state, which enforces the law by means of appropriate penalties or remedies. Legislation for behaviour warrants focus upon the legality of an action and not the morality of such action. This study seeks to examine the efficacy of the law that guarantees sustainable economic development and against corruption, fraud, and cybercrimes in a society.

\section{Politics}

Politics is all activities that are related to the forces of management and control of a particular group, or persons, or societies as an organized state. It is the science of exercising power

\footnotetext{
${ }^{2}$ Nzamujo open lecture at a seminar for youth development in Nigeria Enugu s (2014),
} 


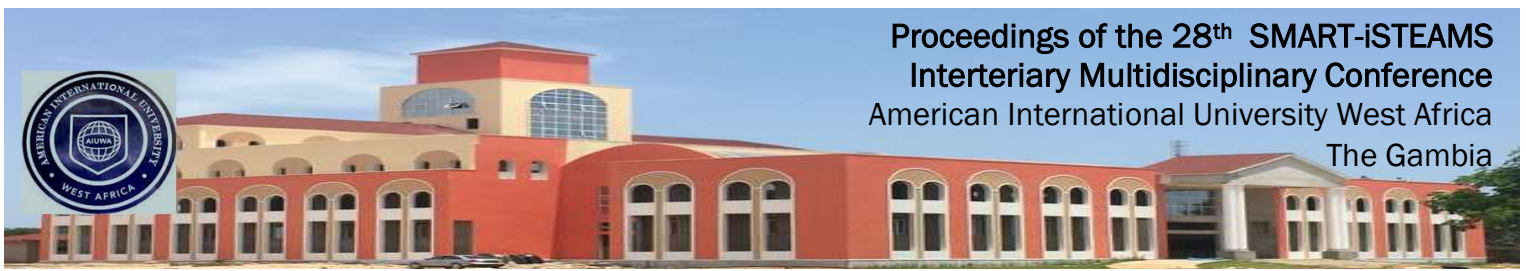

and/or absolute power within a community, an organization or state, including the oversight function of using power and status within the nomenclature rather than with matters of principle. "politics consists of the making of common decisions for a group through the use of power.' 3

\subsection{Contemporary Africa}

The contemporary Africa issue is about politics, economics, social, and technological assessment along poor governance, unemployment, corruption, insecurity, population growth, and, droughts and famine. Contemporary Africa root spanned out of the beginning of contemporary world, with contemporary history comprising the span of historical events that evolved from 1945, after. The contemporary world is an ever-changing mix of social and political changes and, the main focus are - citizenship and community life, taking part in democratic life and developing attitude of openness to the world and respect for diversity. At the same global level today, contemporary issues regarded as burning spare are largely drawn as: Climate Change - the global temperatures are rising, mainly through pollution; others are Violence; Malnourishment and Hunger; Lack of Quality Education; Unemployment; Health Issues; Insecurity; and Government Corruption.

\section{Meaning of Contemporary Issue}

An issue is contemporary when we discuss how the specific currently affect people or place(s), especially when it is yet to be addressed or resolved. With religious, political, and ethnic conflicts today in so many countries of the world, we are currently living in one of the most unrestful eras in the history of the planet and, all these are contemporary issues. Politics as all activities that are related to the forces of management and control of a particular group, or persons, or societies has been paying a lot to the resolve of these problems.

\section{Corruption}

Corruption is a dishonest or *fraudulent conduct by those in power, especially involving typically, bribery or the process by which an expression or word is changed from its original form to an erroneous order-based form including putrefaction. Forms of corruption include the misuse of public power by any appointed civil servant or elected politician for private benefit or gain, and when the law brings down its harmer on corrupt persons and fraudsters, it can cost people their freedom, health, money, and sometimes even life. "Corruption corrodes the fabrics of society and undermines people's trust in political and economic systems, institutions and leaders" 4

\section{Fraud}

Fraud as a name and an action is described by many words like extortion, cheat, embezzlement, swindle, scam, double-cross, ploy, hoodwink, hoax, (and in Nigeria -419), and corruption, including perversion or concealment of truth, to gain unlawful or unfair advantage over someone or organization or state. Today in many countries of Africa, corruption and fraud has eaten deep into the caprices of governments, and non-government institutions, and even in individual relations that it has become systemic.

\footnotetext{
${ }^{3}$ Shively, politics and power (2001),

${ }^{4}$ Transparency international 2020.
} 


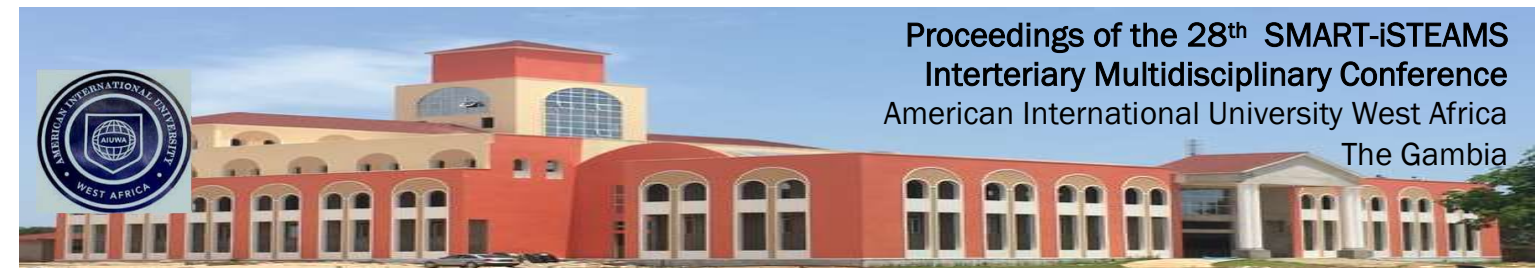

As against exploitation of occasional opportunities, a systemic corruption occurs when corruption become an integrated part or essential aspect of the economic, social and political system of a society- this is presently what is obtainable in Africa. In its legal definition, fraud is false representation of a matter of fact, whether by words or by conduct i.e. by misleading or false allegations. These also include the concealment of what ought to have been disclosed, that deceives and, is intended to deceive another so that that individual act upon his or her detriment -5 West's Encyclopedia of American Law (2008).

\section{Cybercrime}

Cybercrime is any unlawful or criminal activity that involves a computer or internet or network connected devices, such as mobile phone as the tool or device used or in use by the agent of the crime or fraudster as the case may be. It is any crime committed using a computer network or hardware device. Cybercrime covers a wide range of different attacks, which deserve a unique approach to improving computer safety and protecting the individual or organization or state. This involves extortion, planning or carrying out terrorist activities, blackmail, manipulation, etc.

To ascertain the existing level of prudent leadership and political order in contemporary Africa that addresses violation of rule of law, corruption, fraud, cybercrime, and to determine whether the African leaders have respect for rule of law; one would ask: Does prudent leadership and political order exist in contemporary Africa? And What level or measure of equity and justice is in display or is provided by courts in African countries? The concept of leadership is to provide social contract which guides followers or other member of an entity, or society to clearly define consent of parties involved in leadership and followership for economic gains and social tranquility.

The study of motivation is concerned basically with why people behave the way they do, or in a certain manner and, can be described as the persistence and direction of action which is concerned with why people choose a particular course of action in preference to others, and why they continue with such action, movement or struggle. With the complexities of life at present in the world, and Africa specifically, it becomes important to loot at why leaders in Africa behave the way they do? It is pertinent therefore to ask why for instance the only clause that African presidents see in their sovereign constitutions is the tenure of "the president?" One would want to run for a third term, and the other will want the constitution to make it as many times as the incumbent president can win election, with the orgy in political campaigns.

\footnotetext{
${ }^{5}$ West's Encyclopedia of American Law (2008).
} 


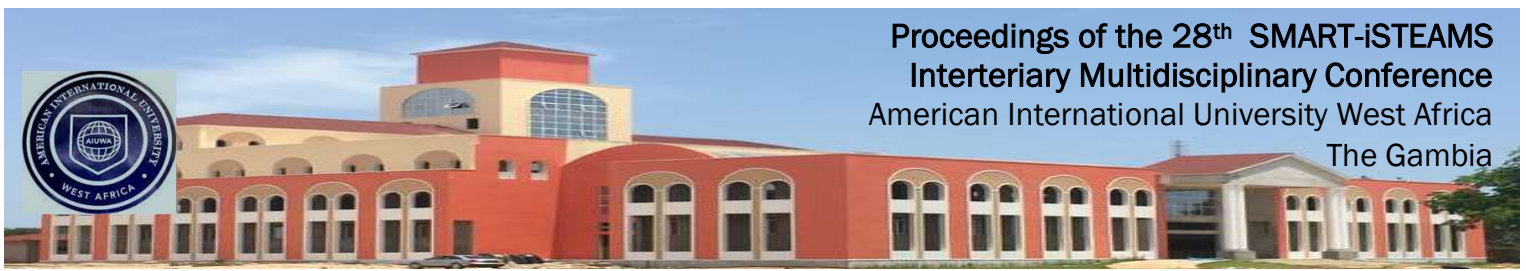

\section{REVIEW OF RELATED LITERATURE}

\section{Theories of Law, Corruption, Fraud and Cybercrime}

Law

Every business needs to deal with legal matters and, because of the nature of legal tasks as daunting issue, a solicitor or solicitors may be required to help with legal matters that may arise. Law is not completely a matter of human enactment as it also includes 'natural law.' It is said that the best-known version of the law of nature is, that God's law is supreme and has had considerable influence in the legal system of many societies in the world and Africa. Formal legal rules and actions are usually distinguished from other means of social control and guides for behaviours such as mores, morality, public opinion, and other instincts of custom and tradition.

\section{Corruption and Fraud in Africa}

According to Andrew Bettie, "A true history of fraud is traced to 300B.C. when Greek merchant, Hegestratos got a large insurance policy known as bottomry. In the deal the merchant borrowed money and agrees to pay it back with interest when the cargo, corn is delivered. If the loan is not paid back it is agreed, the lender can acquire the boat and its cargo."

Hegestratos planned to sink his empty boat, keep the loan and sell the corn. This did not work out, and he got drowned trying to escape his crew passengers when they caught him in the act. This is the first recorded incident of fraud as there may have been other ones since the beginning of Commerce. A few years after America officially became a nation, the first fraud occurred in 1792 of trading and bond scandal. Ulysses S. Grant was a former President and a renowned war hero. He only wanted to help his son, Buck, succeed in business, but ended up causing a financial panic through misrepresentation or identity fraud.

Report: Trinity University by Bob Jensen one of the best known fraud was the 1626 purchase of Manhattan Island for trinkets value at 60 guilders (approximately $\$ 24$ ), and perpetrated by Carnarsie Indians from Brooklyn 6 - Government acquisitions of land have afforded expanding opportunities for legislators (or their agents) and government bureaucrats to accept bribes and otherwise collaborate with land swindlers. In 1787 fewer than 40 corporations operated in the US, and contract with government to build roads, bridges, canals, dams, and other public projects. Many of the projects were burdened with bribes, kickbacks, and inflated prices.

\section{Financial Crime and Fraud}

History is full of Scams and Frauds that removed billions of dollars from the pockets of governments and investors and destroyed entire economies

The most famous forgeries according to Guardian.co.Uk have taken place in the $20^{\text {th }}$ century, by "Etruscan" terracotta warriors that were sold to the New York met between 1915 and 1921.

\footnotetext{
${ }^{6}$ - www.trinity.edu/rjensen/FraudA
} 


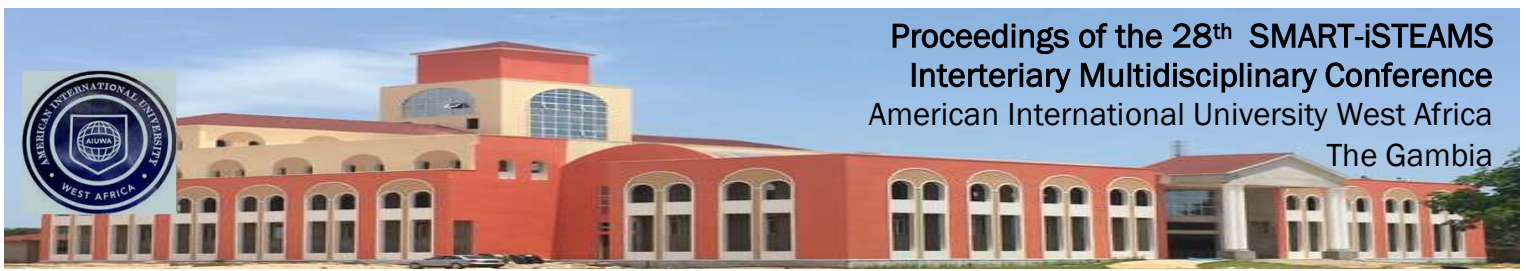

Fraud Laws

In Nigeria one of the laws that control fraud offences is the Advance Fee Fraud and other Fraud Related Offenses Act 2006 - Laws of the Frederation of Nigeria. Notwithstanding anything contained in any other enactment or law, any person who by any false pretence, and with intent to defraud

a) obtains, from any other person, in Nigeria or in any other country for himself or any other person;

b) induces any other person, in Nigeria or in any other country, to deliver to any person; or

c) obtains any property, whether or not the property is obtained or its delivery is induced through the medium of a contract induced by the false pretence, commits an offence under this Act.

A person who by false pretence, and with the intent to defraud, induces any other person, in Nigeria or in any other country, to confer a benefit on him or on any other person by doing or permitting a thing to be done an understanding that the benefit has been or will be paid for commits on offence under this Act. A person who commits an offence under subsection (1) or (2) of this section is liable an conviction to imprisonment for a term of not more than 20 years and not less than seven years without the option of a fine.

\section{What the Law Says About Fraud}

While the exact wording of fraud charges varies among state and federal laws, the essential elements needed to prove a fraud claim in general include:

1) a misrepresentation of a material fact;

2) by a person or entity who knows or believes it to be false;

3) to a person or entity who justifiably relies on the misrepresentation; and

4) actual injury or loss resulting from his or her reliance.

Most states require that each element be proven with "particularity" - meaning that each element must be separately proven for a fraud charge to stand. In law, fraud is deliberate deception to secure unfair or unlawful gain, or to deprive a victim of a legal right. Fraud itself can be a civil wrong (i.e., a fraud victim may sue the fraud perpetrator to avoid the fraud and/or recover monetary compensation), a criminal wrong (i.e., a fraud perpetrator may be prosecuted and imprisoned by governmental authorities) or it may cause no loss of money, property or legal right but still be an element of another civil or criminal wrong. The purpose of fraud may be monetary gain or other benefits, such as obtaining a driver's license or qualifying for a mortgage by way of false statements.

Laws against fraud vary from state to state, and can be criminal or civil in nature. Criminal fraud requires criminal intent on the part of the perpetrator, and is punishable by fines or imprisonment. Civil fraud, on the other hand, applies more broadly to circumstances where badfaith is usually involved, and where the penalties are meant to punish the perpetrator and put the victim back in the same position before the fraud took place. A hoax is a distinct concept that involves deliberate deception without the intention of gain or of materially damaging or depriving a victim. 


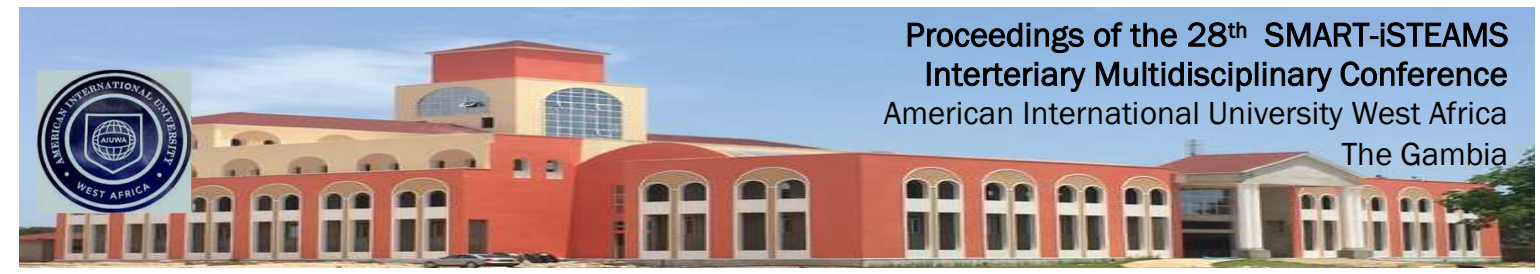

A corrupt practice include: the offering of and/or giving, receiving or soliciting, directly or indirectly, anything of value to influence improperly the actions of another party, including artificially inflating project financing (and execution) costs - ${ }^{7}$ Nwele (2013). The sale of the Roman Empire in (193 A.D.) by a Praetorian Guard, to Julianus (at 250 gold pieces to every of the army member; all amounting to equivalent of today's $\$ 1$ billion) as highest bidder, this also is fraud.

In 1496, Michelangelo faked a piece of Sculpture and sold it to Cardinal Riario of San Giorgio, again, it is fraud. Prudence as a principle requires organisations or companies to report on their balance sheet, the value of their assets and liabilities at their least favorable valuation. Prudence demands that revenue is not recognised unless it is certain, while expenses are recognised while they are probable - meaning that income/expense recognition and projections should be realistic. Real community problems are likely to be complex. Economic development may depend on the global economy, a force you can't have much effect on. You may have opposition, either from within the community itself, or from powerful forces trying to protect their own interests. Community problems exist precisely because they often resist clear analysis and solution. They persist despite our efforts, and they can be real challenges

\section{Fraud Laws}

Fraud Law covers a broad range of crimes and civil tort actions that address situations in which a person wrongfully obtains money, property, or other benefits by deceit. In the criminal context, fraud is typically charged as a felony, meaning that a conviction can result in a year or more of incarceration. Criminal penalties can also include statutory fines, restitution (victim reimbursement), community service, as well as the loss of civil rights associated with a felony conviction. In civil court, financial compensation is generally the plaintiff's sole remedy. Fraud cases can be brought in either state or federal court.

The sale of the Roman Empire in (193 A.D.) by a Praetorian Guard, to Julianus (at 250 gold pieces to every of the army member; all amounting to equivalent of today's $\$ 1$ billion) as highest bidder, this also is fraud. In 1496, Michelangelo faked a piece of Sculpture and sold it to Cardinal Riario of San Giorgio, again, it is fraud. How do we solve the many problems of resource mobilization and inclusion for inclusive growth of an economy? One of recent questions asked about leadership, according to "The Economist" economist.com is how can leaders set the right tone for returning to offices and reflecting upon the future of work?

\footnotetext{
${ }^{7}$ Nwele Obasi , Credit and Risk Management in Business Administration: the Problem and Prospects," an unpublished seminar paper, presented at 'Training the Trainers Workshop, Bauchi, 2013.
} 


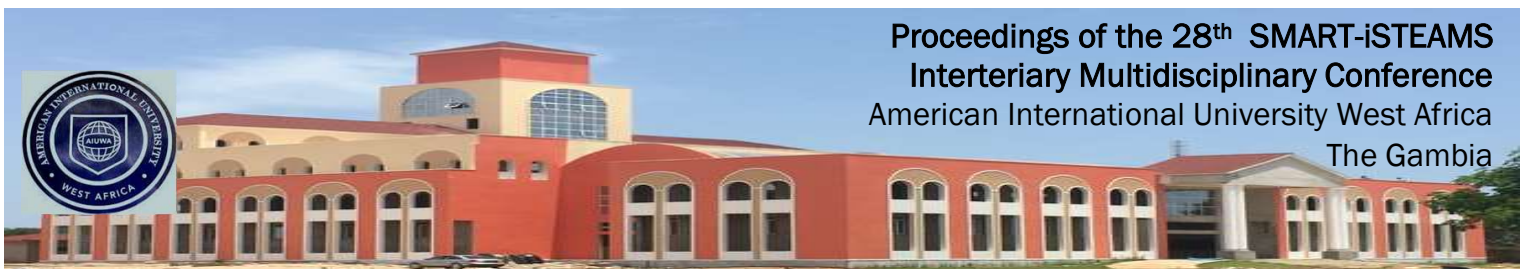

\section{EMPIRICAL ANALYSIS}

How do we solve the many problems of resource mobilization and inclusion for inclusive growth of an economy? The major qualities of a good leader include positivity and resilience built on integrity, accountability, empathy, humility, vision, influence, and inspiring people to do things they never thought they could. Great leaders are also known to have listening skills, critical thinking, time management, planning, organization, delegation, implementation and feedback, motivation and collection of results. Good leaders help themselves and others to do the right things.

Leadership means different things to different people around the world, and different things in different situations. For instance, it could relate to community leadership, religious leadership, political leadership, and leadership of campaigning groups. This article focuses on the Western model of individual leadership, and discusses leadership in the workplace rather than in other areas. Resistance can be positive, as well as negative. What may look like is resistance is sometimes simply a lack of clarity. You need to clarify the reasons and know when to allow resistance to run its course and when to intervene.

Fraud Law covers a broad range of crimes and civil tort actions that address situations in which a person wrongfully obtains money, property, or other benefits by deceit. In the criminal context, fraud is typically charged as a felony, meaning that a conviction can result in a year or more of incarceration. Criminal penalties can also include statutory fines, restitution (victim reimbursement), community service, as well as the loss of civil rights associated with a felony conviction. In civil court, financial compensation is generally the plaintiff's sole remedy. Fraud cases can be brought in either state or federal court. So, African leaders need to develop new collaborative leadership skill that harnesses models that maximally utilize people's skills, increase productivity, and retains high-performing talents with effective performance management tools with reliable structure framework.

\section{DISCUSSION}

It is reported, Nigeria's inaction delays recovery of $\$ 85$ million ex-minister's loot. The United Kingdom is waiting for Nigeria to claim an $\$ 85$ million loot recovered from a former petroleum minister, Dan Etete, according to the Evening Standard of London. ${ }^{8}$

The newspaper reported that federal government's failure to send a proceeds-of-crime submission to the judge of a UK Court is stalling the recovery of the money which is frozen in a NatWest bank account in London.

The $\$ 85 \mathrm{~m}$ is believed to be part of the proceeds from the award of the licence of OPL245 - an oilfield containing an estimated nine billion barrels of crude - made by Etete to Malabu Oil \& Gas, for $\$ 20$ million, said to be tiny fraction of its real value.

\footnotetext{
${ }^{8}$ the Nation newspaper - September 11, 2016
} 


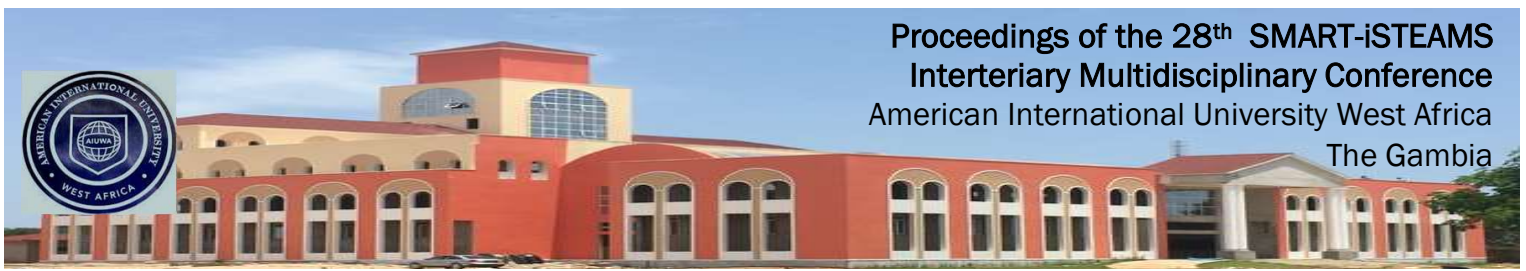

The licence award sparked a multitude of legal suits between Shell and Malabu over the ownership of the field only for federal government to sell the field to Eni and Shell.

$\$ 1.09$ billion of the money paid by the two companies later found its ay to Malabu. Shell and Eni claimed ignorance of who paid the $\$ 1.09$ billion to Malabu.

The newspaper said investigations at Britain's National Crime Agency who are trying to probe the alleged laundering of OPL 245, money through London banks and properties are frustrated by alleged inaction from Nigeria's end.

The Malabu Oil deal is believed to have led to the siphoning off of $\$ 1$ billion from a $\$ 1.3$ billion international investment in the lucrative oil block through 'fees' to Etete's company and middlemen.

High Court Judge, Mr Justice Edis said: "Given the large sums of money involved that are effectively paid to former minister to a bank account in the Middle East, the whole exercise is backed by murky instruction."

The law has been specific about fraud and corruption crimes, for example, in Nigeria there is 'the economic and financial crimes commission (EFCC),' 'the independent corrupt practices commission and other related offences commission (ICPC), etc. Fraud poses the risk of both financial loss and personal danger to their victims.

Sometime in the past, the Cameroonian government started a massive crackdown on Pentecostal churches in the country as President Paul Biya accused them of threatening the security of the country, especially in relation to financial crimes and fraud.

Tendai Ruben Mbofana is a Social Justice activist and commentator, who in an article argued that, the "African Union is nothing more than a dictators' club, which seeks to serve and protect the interests of those in power, at the expense the suffering ordinary people."

The AU succeeded the Organization of African Unity (OAU) in 2001 and till today, still lack vision and creativity. The majority of the estimated 800 million African people are disillusioned and desperate because the continent is on the bottom line of human development indicators, striken with a metaphor for poverty, disease, unemployment, corruption and mismanagement. The bad governance practice has made the continent face the greatest human displacement among all the world's regions.

The director of Financial Intelligence Unit (FIU) of The Gambia and the GIABA national coordinator, Alagie Dardoe, says D60 million was laundered in 2020, while fraud emerged as the most reported financial crime. Accordingly, the funds have been forfeited to the state. ${ }^{9}$ The FIU director made the revelation during the Regional Financial Intelligence Analysis Course for Financial Intelligence Units (FIUs) for five GIABA member states on Monday in Banjul.

\footnotetext{
${ }^{9}$ The Point newspaper (Banjul) - By Sankulleh Gibril Janko:
} 


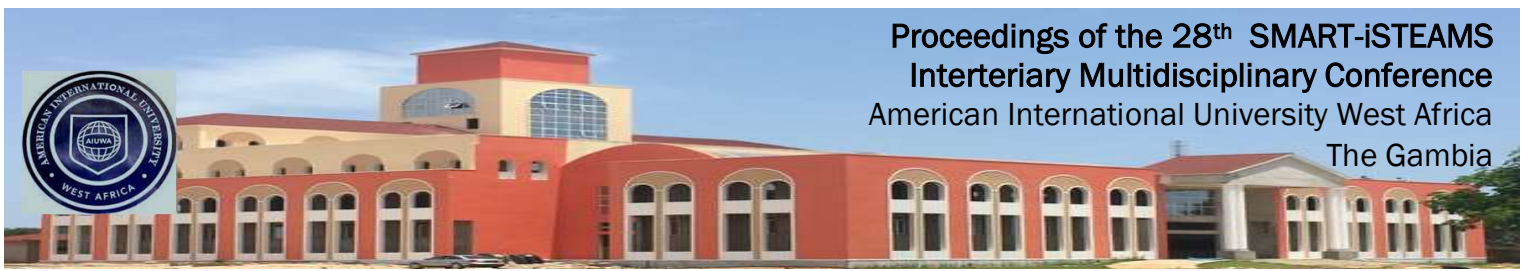

Asked if any financial crimes have been reported in The Gambia recently, Mr. Darboe responded in the positive. "Yes, we have come across a number of them, some were analysed, sent to the police for further investigation and were found to be genuine, some were found to be Gambian, some were analysed sent to the police for investigation and were prosecuted," he said.

He went on: "We even reported a conviction of money laundering in The Gambia where 60 million was laundered through The Gambia and the funds were forfeited to the state."

Meanwhile, according to the Financial Intelligence Units director, fraud was rampant in the previous year accounting for the greater percentage of the financial crimes reported.

Darboe said: "The FIU received a total of 47 transaction reports of which 42 domestic information requests, one international information request in the year 2020."

"In the same year, six international information requests were sent, those CR we received so far in 2020 , fraud emerged as the most reported offence of money laundering accounting for $56 \% . "$ Mr. Darboe urged the selected FIU participants to be more vigilant as reports have emerged showing some people using the Covid-19 as leverage to engage in financial crimes with bogus amounts all in the name of fighting the pandemic.

According to him, issues of counterfeit personal protection equipment, bogus Covid-19 medication as well as online fraud among many other things have been reported.

\section{CONCLUSION}

Considering all that has been discussed, theoretical analysis, the review of related literature and research findings obtained in this study, it has been established that the perspective of corruption encompasses undue influence over public policies, institutions, laws and regulations by vested private interests of African leaders at the expense of the public interest. Political Corruption, when the laws and the regulations are abused by the rulers, side-stepped, ignored, or even tailored to fit their interests. That is by interpretation, when then the legal bases, against which corrupt practices are usually evaluated and judged, are week and further subject to ridicule, encroachment, and downright by the leaders, requires to be prudently controlled in Africa for inclusive development to take its place in governance.

The researcher recommends that prudent leadership and political order in contemporary Africa that addresses violation of rule of law, corruption, fraud, cybercrime, etc and, downsize level or measure of equity and justice in display or provided by courts in African countries be strongly built and maintained by individual African countries and the AU. The law must be made to be effective in the control of every aspect of corruption, fraud, cybercrime, and the punishment for offenders at every level of society. There is a great need for public office holders to eschew greed and envy, which causes fraud, corruption, abuse to the rule of law, financial disorder, and business failure. All these attributes and variables make up the factors that lead to economic recession and orgy of political crisis. 


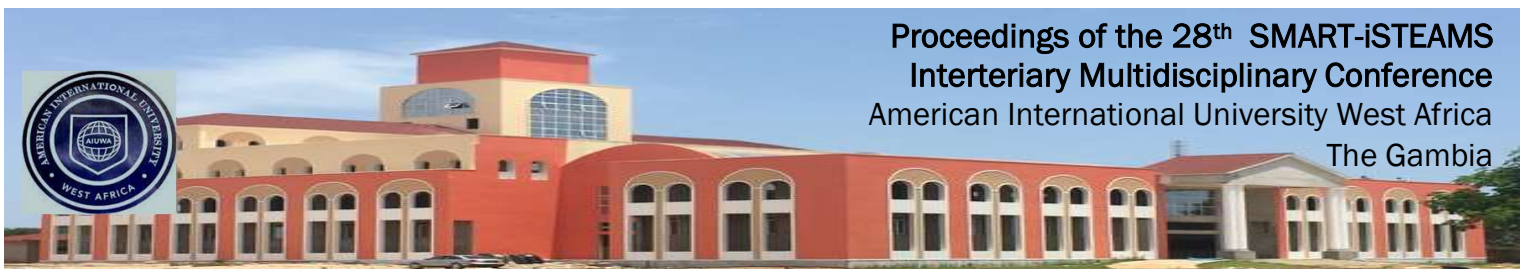

African leaders need to be visionary and creative, with inclusive growth to achieve inclusive development and stability. We need to use experts in \{Cyber security\} to fight fraud and corruption that occur through cybercrime, including research experts working on technical protection against 'Trojan horse virus, and others. We need sound mechanisms for communication and participation, a safe and effective work environment, developing mutual trust in their reliability.

\section{REFERENCES}

1. Jenson Bob, www.trinity.edu/rjensen/Fraud

2. Nwele, JO (2013), "Credit and Risk Management in Business Administration: The Problem and Prospects," an unpublished seminar paper, presented at "Training the Trainers Workshop, International University Bamenda, Cameroon

3. West's Encyclopedia of American Law, edition 2. Copyright 2008, The Gate Group, Inc. All rights reserved.

4. Nzamujo open lecture at a seminar for youths' development in Nigeria Enugu 2014

5. Shively, politics and power (2001)

6. Transparency International 2020

7. The nation newspaper September 2016

8. Nwele Obasi, Law and practice of management in a contemporary society seminar in management class project report, Renaissance University - Enugu (2014) 